\title{
Editorial
}

\section{Intervention: Elsevier, the arms trade, and forms of protest - A response to Chatterton and Featherstone}

In their recent intervention in Political Geography (2007, vol 26, 1) Chatterton and Featherstone bring to the attention of geographers the role of Reed Exhibitions in the organisation of the Defence Systems and Equipment International (DSEI) exhibition held in London every second year. Reed Exhibitions is part of the Reed Elsevier group of companies of which Elsevier Publishing, the publisher of Political Geography and several other geography journals (Applied Geography, Geoforum, Journal of Historical Geography, Journal of Rural Studies), plus geography books, and the forthcoming International Encyclopedia of Human Geography (IEHG), is a member. In their intervention they argue that DSEI constitutes an 'arms trade fair' and call for a boycott of all Reed Elsevier companies and products (in terms of submitting articles, refereeing papers, editing journals, writing and editing books) on the basis that continuing to work with the Reed Elsevier group adds to the profits of a corporation complicit in the arms trade. ${ }^{1}$

As someone who is contracted as co-editor-in-chief of the forthcoming IEHG, the call to boycott all Reed Elsevier endeavours has raised a number of thorny questions, issues and challenges. I have been both privately and publicly asked to justify why I continue to work on the IEHG project and why contributors should persist in producing entries. In this short intervention, I want to respond to Chatterton and Featherstone's call for a boycott of Elsevier publications, extend Hammett and Newsham's (2007) rejoinder calling for a wider debate on the links between the academy and defence industries, and explain why I will continue to work to see the IEHG to successful publication. Working through this issue has been very difficult for myself and the other editors who have found ourselves caught in a situation not of our making and which has posed serious ethical dilemmas concerning our own continued involvement in the project. I want to make it clear that I am not an apologist for Reed Elsevier and I have written and spoken to Reed Elsevier's senior management arguing that they need to reflect upon their corporate moral responsibilities and modify their practices accordingly. This is an on-going debate.

DOI of original article: 10.1016/j.polgeo.2006.07.003.

\footnotetext{
is As this issue went to press, Reed Elsevier announced that it would exit the defence exhibitions business: http://www.reed-elsevier.com/index.cfm?articleid=2084.

${ }^{1}$ As of April 26th 2007, 16 people had officially boycotted the IEHG, all but one of whom are located in the UK.
} 


\section{Reflecting on the protest to date}

Clearly everyone should have the right to voice their concerns about particular practices and networks and to protest against such endeavours. This is the case with respect to the organisation of the DSEI and Reed Elsevier and I broadly welcome the ambitions of the campaign. That said, I feel that the nature of the protest does need to be reflected upon in a number of respects.

\section{An oversimplified landscape}

Chatterton and Featherstone argue that Reed Elsevier should uphold the values of the academics it publishes and disinvest from the DSEI as their view being involved with defence industries as fundamentally 'incompatible with the role of publishing international academic journals' (p. 4). Many will agree with those sentiments. Academia though, as Hammett and Newsham (2007) note, is equally complicit in the military-industrial complex. For example, many universities have research contracts or university-industry links with defence industries, including the development of weapons technologies, and university pension and endowment funds are invested in defence companies. Within Geography, the Association of American Geographers has a military geography specialty group and the Royal Geographical Society has a long history of military links, and numerous geographers use declassified military satellite data in their research and work on defence contracts most notably relating to GIS for homeland security $^{2}$ and military planning. ${ }^{3}$ While sympathetic to the call for Reed Elsevier to disinvest from DSEI, I am uneasy about a protest that is narrowly conceived, consisting of a single action $^{4}$ that largely ignores the many complex and contradictory ways that academia (and indeed Geography) is enmeshed with military and defence industries, ${ }^{5}$ and uses a primary tactic that penalises academics themselves. I would prefer to see a much broader debate about the relationship between academia and the military-industry complex, and a campaign that utilises a more diverse set of strategies.

\section{Cutting off our noses to spite our faces}

The campaign as presently conceived, while effectively expressing the anger and disappointment of the protestors, does work to punish academics for the sins of the publishing company. First, boycotting Elsevier Publishing works to limit the places where we can publish our work and thus closes off important opportunities for critical scholarship and debate about the very things that need opening up for scrutiny and reflection. Second, these publications are the means by which many academics are evaluated with respect to research assessment exercises (as in the UK), tenure and promotion. In other words, academics are being asked to doubly

\footnotetext{
${ }^{2}$ http://www.esri.com/events/homeland/index.html.

${ }^{3}$ GIS was a key planning and decision tool in the first Gulf war and in the present 'war on terror'.

${ }^{4}$ To date the campaign has remained firmly focused solely on Reed Elsevier with no other publisher targeted despite the fact that many have links to military and state institutions and publish journals focused on military strategy and developments, nor academic bodies (specific projects, departments, or universities) or disciplinary institutions (such as the RGS or AAG) or indeed the arms companies themselves.

${ }^{5}$ Like private companies, universities and academics choose to bid for and accept defence and military contracts; they are not compelled to accept them and are therefore open to the same criticisms and protests aimed at Reed Elsevier.
} 
punish themselves by protesting through a strategy of boycott. Moreover, the editors and editorial board members of projects published by Elsevier, people who work hard on behalf of their disciplines and colleagues and have found themselves in a very difficult position through no fault of their own, are having their work systematically attacked and undermined. While solely targeting one publication, as has been advocated with respect to IEHG on the critical geography forum mailing list, might seem to mitigate some of these issues by keeping the journals free of the boycott, it rather unfairly singles out and undermines a project that hundreds of people have already written for and which is progressive and critical in nature.

\section{Ends and means}

It seems to me that in these circumstances boycotting should be used as a last resort with other strategies initially pursued. Ideally I would prefer a campaign that was more broadly focused on the relationship between academia and the military-industrial complex, and which started by targeting more directed the arms industry, the state, and the media. If this did not meet with a successful end then a campaign directed specifically at the DSEI and to key decision makers in Reed Exhibitions could be a next step. Again if this failed, the campaign should then move to Elsevier Publishing, perhaps initially seeking the cancellation of library and personal subscriptions - hitting the bottom line - or writing letters of protest to see if Reed Elsevier's practices could be shifted. For example, some protestors have written directly to Elsevier expressing their views and have completed their entries using the arms issue as illustrative material, which I feel is a productive strategy that adds to the critical scholarship of the discipline and will help inform students and others of this issue in the long term. While boycotting is certainly a powerful form of protest, and one that leverages direct consequences for the target, it also penalises those protesting and their colleagues when other forms of protest might have initially succeeded. When those working on Elsevier projects have suggested other forms of protest they have in some instances been unfairly and unjustly branded as siding with the enemy and being apologists for the publisher. Rather, they are too actively campaigning against this issue, but from inside a project. ${ }^{6}$

\section{Why continue to work on the International Encyclopedia of Human Geography?}

\section{Progressive project}

The IEHG is a large, international collaboration that will provide a valuable overview of human geography from around the world. The encyclopedia will include detailed entries on every field of human geography, philosophy and theory, key concepts, methods and practices, biographies of notable geographers, and geographical thought and praxis in different parts of the world. As a web resource it will be accessible to academics and students from across the planet. Unlike most Geography projects, editors and authors are drawn from a number of countries. It is therefore helping to establish a dialogue that bridges divides and starts to tackle issues of Anglo-American dominance in the production of such works. This is, we believe, an important political endeavour and deserves to be completed (see Kitchin, 2007 for a number of

\footnotetext{
${ }^{6}$ For example, pressing for a change in business practices by Reed Elsevier and encouraging critical scholarship on the issue.
} 
articles discussing this issue). To sacrifice one political project for another, especially when one has not tried any other form of campaigning, would create a huge missed opportunity. Further, I believe that the IEHG will be a significant collection of critical scholarship, with many of the issues discussed in various fora on military and 'defense' industries, plus many other significant political, social, cultural and economic issues, addressed in the entries, allowing students and fellow academics to think through them and thus inform their own praxis.

\section{A web of obligations}

As co-editor-in-chief of IEHG I have three predominate sets of obligations: to my fellow editors; to those contributors who have signed contracts to produce entries, many of whom have already written their articles; and to Elsevier Publishing. In the first two cases, my co-workers have invested significant time and intellectual capital to the project. I have also spent hundreds of hours working on the project. I am bound within a set of obligations to see the IEHG to completion. Withdrawing from the project at this stage would mean that hundreds of people who have produced material would have wasted significant time and energy. As argued above, I would be penalising fellow academics and myself when other political strategies of protest might be more productively pursued (at least in the first instance). And I certainly can't assume to speak for fellow editors and contributors by seeking to terminate the project on ethical grounds when they might be perfectly okay with Reed Elsevier's business practices. ${ }^{7}$

\section{Conclusion}

I want to be clear that I am not advocating that academics should do nothing with respect to the links between academia and the arms industry, or against Reed Exhibitions' organisation of the DSEI in particular, but I do think the present campaign being waged against Elsevier Publishing, and the IEHG in particular, is not the most productive strategy in the first instance: it works to penalise scholars, create unnecessarily divisions between them, and curtails the publication of critical scholarship that seeks to address this and other political issues. Instead, I would prefer to see a wider, differently formulated campaign which promotes progressive scholarship and in which boycotting is a last, rather than first, resort tactic.

\section{Acknowledgements}

I am grateful to the other editors of IEHG for the many conversations about the issues discussed in this intervention. However, the views expressed are solely those of the author and do not necessarily reflect their viewpoints.

\section{References}

Chatterton, P., \& Featherstone, D. (2007). Intervention: Elsevier, critical geography, and the arms trade. Political Geography, 26, 3-7.

\footnotetext{
${ }^{7}$ And remember this project began long before the issue came to light and the present campaign started.
} 
Hammett, D., \& Newsham, A. (2007). Intervention: widening the ethical debate - academia, activism and the arms trade. Political Geography, 26, 10-12.

Kitchin, R. (Ed.). (2007). Mapping Worlds: An international perspective on social and cultural geography. London: Routledge.

R. Kitchin

National University of Ireland, Maynooth, County Kildare, Ireland E-mail address: rob.kitchin@nuim.ie 